\title{
Methane distribution, sources, and sinks in an aquaculture bay (Sanggou Bay, China)
}

\author{
Jing Hou ${ }^{1,2}$, Guiling Zhang ${ }^{1,2, *}$, Mingshuang Sun ${ }^{1}$, Wangwang Ye ${ }^{1}$, Da Song ${ }^{1}$ \\ ${ }^{1}$ Key Laboratory of Marine Chemistry Theory and Technology, Ministry of Education, Ocean University of China, \\ Qingdao 266100, PR China \\ ${ }^{2}$ Qingdao Collaborative Innovation Center of Marine Science and Technology, Ocean University of China, Qingdao 266100, \\ PR China
}

\begin{abstract}
From 2012 to 2015, we investigated methane $\left(\mathrm{CH}_{4}\right)$ distribution, air-sea fluxes, and sediment-water fluxes in an aquaculture bay (Sanggou Bay, China), and estimated the input of $\mathrm{CH}_{4}$ from potential land sources including rivers and groundwater. Surface water $\mathrm{CH}_{4}$ in the bay ranged from 3.0 to $302 \mathrm{nM}$, while bottom $\mathrm{CH}_{4}$ was usually higher due to sediment release. Water column $\mathrm{CH}_{4}$ in summer and autumn was 3 to 10 times that in spring and winter due to seasonal variation in water temperature and land source inputs. Surface $\mathrm{CH}_{4}$ was higher in kelp and scallop polyculture zones than in other culture zones and outside the bay, suggesting the influence of aquaculture activities. $\mathrm{CH}_{4}$ concentrations were 123 to $2190 \mathrm{nM}$ in rivers around the bay, and 1.6 to $405 \mathrm{nM}$ in groundwater along the shoreline; both showed great spatial and temporal variations. Sediment-water $\mathrm{CH}_{4}$ fluxes ranged from 0.73 to $8.26 \mu \mathrm{mol} \mathrm{m}^{-2} \mathrm{~d}^{-1}$, with those in bivalve culture zones higher than in polyculture zones. Sea-air $\mathrm{CH}_{4}$ fluxes ranged from 2.1 to $123.2 \mu \mathrm{mol} \mathrm{m}{ }^{-2} \mathrm{~d}^{-1}$ (mean $48.2 \mu \mathrm{mol} \mathrm{m}{ }^{-2} \mathrm{~d}^{-1}$ ) and showed seasonal variations. $\mathrm{CH}_{4}$ budget in Sanggou Bay showed that groundwater input $\left(4.2 \times 10^{5} \mathrm{~mol} \mathrm{yr}^{-1}\right)$ was the largest source of $\mathrm{CH}_{4}$, followed by sediment release $\left(2.6 \times 10^{5} \mathrm{~mol} \mathrm{yr}^{-1}\right)$ and riverine input $\left(1.4 \times 10^{5} \mathrm{~mol} \mathrm{yr}^{-1}\right)$, while sea-to-air release $(2.5 \times$ $\left.10^{6} \mathrm{~mol} \mathrm{yr}^{-1}\right)$ and export from the bay to the Yellow Sea $\left(8.8 \times 10^{5} \mathrm{~mol} \mathrm{yr}^{-1}\right)$ were the dominant $\mathrm{CH}_{4}$ sinks. Net water column production-oxidation was estimated preliminarily to produce $1.7 \times$ $10^{5} \mathrm{~mol} \mathrm{CH}_{4} \mathrm{yr}^{-1}$. However, there was a great imbalance of sources and sinks, with an apparent missing source of $2.4 \times 10^{6} \mathrm{~mol} \mathrm{yr}^{-1}$ that was mostly due to an underestimate of in situ water column production and $\mathrm{CH}_{4}$ release from the sediments.
\end{abstract}

KEY WORDS: $\mathrm{CH}_{4} \cdot$ Sanggou Bay $\cdot$ Production $\cdot$ Sediment-water exchanges · Air-sea fluxes · Aquaculture

\section{INTRODUCTION}

Methane $\left(\mathrm{CH}_{4}\right)$, the most abundant hydrocarbon in the atmosphere, plays an important role in regulating the Earth's radiation balance and atmospheric chemistry in the troposphere (Cicerone \& Oremland 1988, Lashof \& Ahuja 1990). Although the current atmospheric mixing ratio of $\mathrm{CH}_{4}(\sim 1.8 \mathrm{ppm})$ is much less than that of $\mathrm{CO}_{2}(\sim 390 \mathrm{ppm})$, it is actually responsible for about $20 \%$ of the greenhouse effect (IPCC 2013). The atmospheric $\mathrm{CH}_{4}$ mixing ratio has increased by a factor of 2.5, from $722 \mathrm{ppb}$ in 1750 to $1803 \mathrm{ppb}$ in

\footnotetext{
*Corresponding author: guilingzhang@ouc.edu.cn
}

2011, as a result of human activities since the Industrial Revolution (IPCC 2013).

Oceans are a natural source of atmospheric $\mathrm{CH}_{4}$, and there are large spatial and temporal variations of oceanic $\mathrm{CH}_{4}$ emissions. Typically, oligotrophic waters are only slightly supersaturated (by about $5 \%$ ) in $\mathrm{CH}_{4}$ with respect to atmospheric equilibrium (Bates et al. 1996, Bange et al. 1998, Karl et al. 2008), resulting in low sea-to-air $\mathrm{CH}_{4}$ fluxes. High sea-to-air $\mathrm{CH}_{4}$ emissions can occur in biologically productive regions such as estuaries and coastal and upwelling areas, which contribute to about $75 \%$ of the oceanic

๑ The authors 2016. Open Access under Creative Commons by Attribution Licence. Use, distribution and reproduction are unrestricted. Authors and original publication must be credited. 


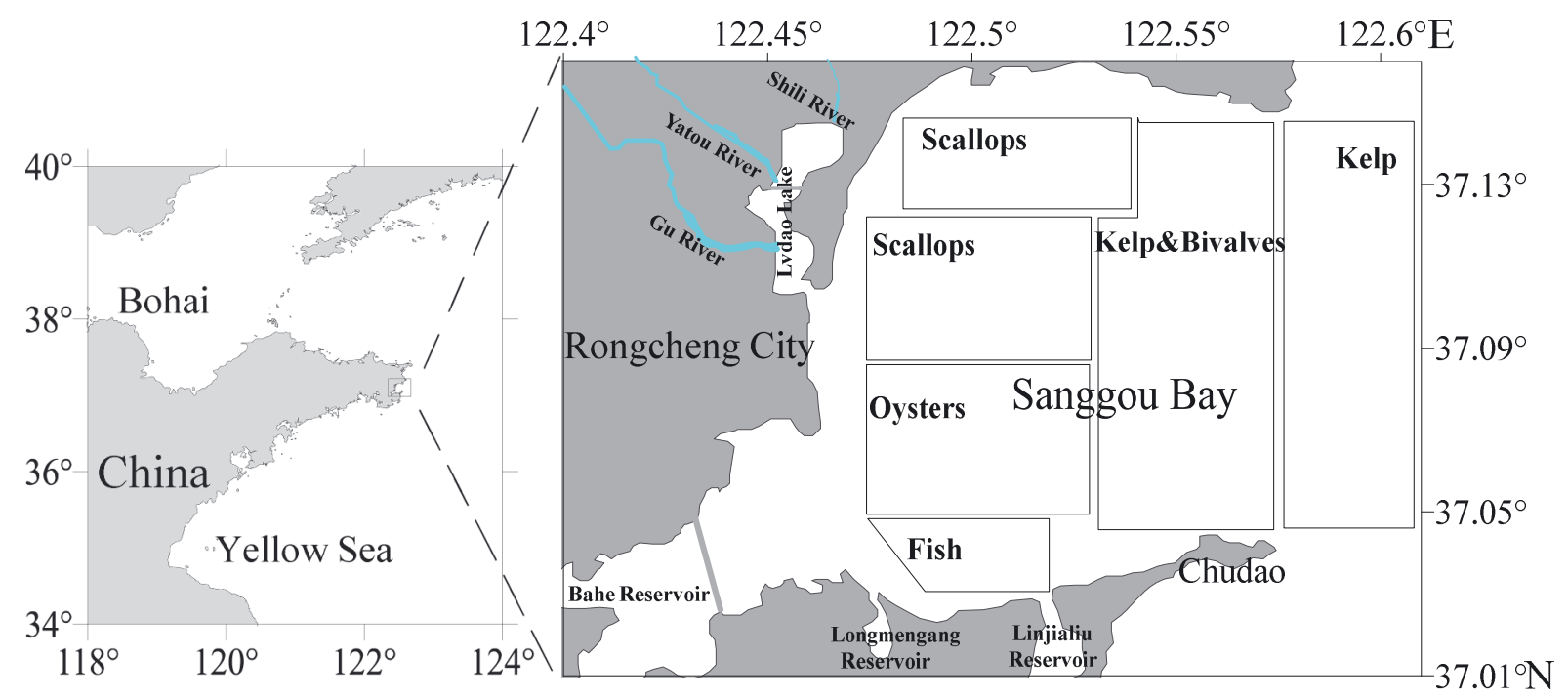

Fig. 1. Location of Sanggou Bay, China, and the main aquaculture practices

$\mathrm{CH}_{4}$ emissions (Bange et al. 1994, EPA 2010). However, $\mathrm{CH}_{4}$ emissions from coastal areas still have great uncertainties, due to poor coverage of $\mathrm{CH}_{4}$ measurements and great spatial variations. Potential sources of $\mathrm{CH}_{4}$ in coastal waters include riverine inputs, in situ water column production, and sediment release (Martens \& Klump 1980, Kelley et al. 1990, Hornafius et al. 1999, Mau et al. 2007, Canet et al. 2010). It is generally assumed that $\mathrm{CH}_{4}$ production and emission from coastal waters will be enhanced with the increase in human perturbations such as increased nutrient loading and intensive marine aquaculture. With the continuous decline in fishery harvests, aquaculture has become the world's fastest growing sector of food production, increasing nearly 60 -fold during the last 5 decades, to meet the increasing demand for seafood (FAO 2007). However, the rapid increase in aquaculture production may also cause some environmental concerns, such as the release of greenhouse gases (Ferrón et al. 2007, Green et al. 2012). The discharge of effluent with high concentrations of organic matter and nutrients from coastal aquaculture systems to adjacent marine waters can lead to organic pollution and provide favorable conditions for the production of $\mathrm{CH}_{4}$. However, most studies on coastal methane emissions have focused on estuaries and coastal waters, and few studies have been conducted on coastal aquaculture systems. The aims of this study were to determine the temporal and spatial distributions of $\mathrm{CH}_{4}$ in an intensive coastal aquaculture bay (Sanggou Bay) in China, to identify various $\mathrm{CH}_{4}$ sources and sinks, and to evaluate $\mathrm{CH}_{4}$ emissions from this bay and the possible impact of aquaculture activities.

\section{MATERIALS AND METHODS}

\section{Study area}

Sanggou Bay (SGB) is a semi-circular bay on the north-eastern coast of China (Fig. 1). The bay is crescent-shaped, facing the Yellow Sea in the east, and has an average water depth of approximately $7.5 \mathrm{~m}$ and an area of approximately $144 \mathrm{~km}^{2}$ (Zhang et al. 2009). Water renewal between the bay and the Yellow Sea is driven by a semi-diurnal tide with the largest tide range of $3.5 \mathrm{~m}$. When the tide is rising, the tidal water enters the bay from the north, rotates counterclockwise, and flows out from the south through the west coast of the bay. The ebb tide has the reverse process, and the velocity of the residual flow is slow (Chinese Gulf Compilation Committee 1991). The main rivers emptying into the bay include the Sanggan, Ba, Shili, and Gu Rivers, with the total annual water discharge ranging between $1.7 \times 10^{8}$ and $2.3 \times 10^{8} \mathrm{~m}^{3} \mathrm{yr}^{-1}$ (Jiang et al. 2015). The largest river, i.e. the $\mathrm{Gu}$, provides almost $70 \%$ of the total water discharge.

SGB has been used for aquaculture since the mid1980s and is among the largest aquaculture sites in China (Guo et al. 1999, Zhang et al. 2009, Jiang et al. 2015). About $2 / 3$ of the bay area is used for farming of bivalve shellfish, seaweed, and fish, with 4 major types of culture model, i.e. the monoculture of kelps, the monoculture of scallops, the monoculture of oysters, and the polyculture of kelps and bivalves (Fig. 1) (Shi et al. 2013). The main cultivation method is longline culture, and cultivated species include kelp Saccharina japonica, scallops Chlamys farreri, and oys- 


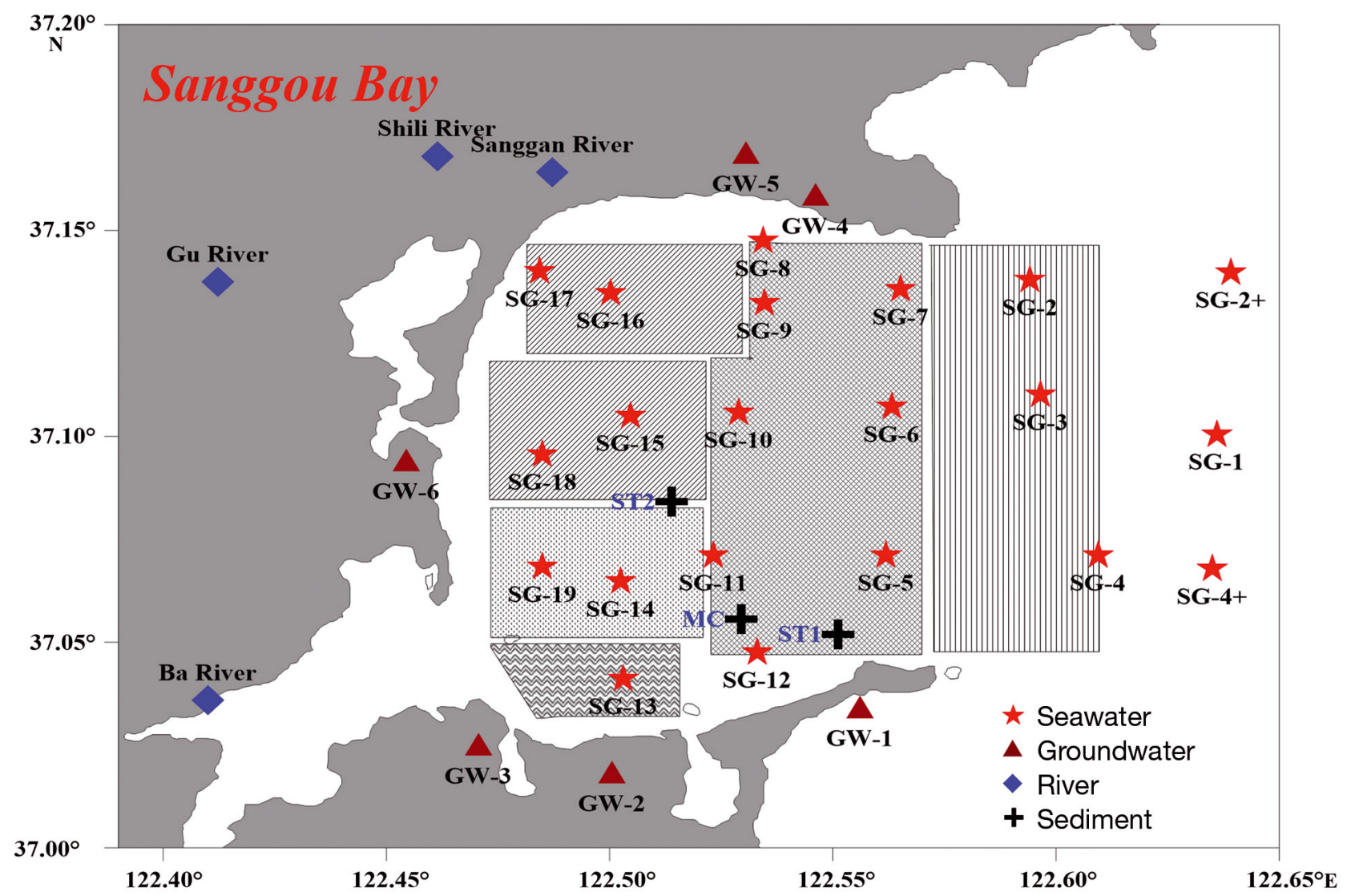

Fig. 2. Sampling locations in Sanggou Bay. Polygons delineate aquaculture types, see Fig. 1

ters Crassostrea gigas (Zhang et al. 2009). Kelp is tied to ropes and scallops are contained either in lantern nets or by ear-hanging (Zeng et al. 2015). Macroalgae (i.e. kelp) are grown outside the bay and only between November and May (Fang et al. 1996). During the seeding and harvesting period, kelp competes with phytoplankton for the assimilation of dissolved inorganic nitrogen. The aquaculture of bivalve shellfishes occurs from early spring to November. Shellfishes filtrate and ingest particulate matter and digest phytoplankton and particulate organic matter (POM), especially oysters when they have spawned in August, demanding more energy and stored substances (Mao et al. 2006). Most fish culture is clustered together in the southern part of the bay where water is calm and cages are within easy access from the shore (Fig. 1).

\section{Water sampling and analysis}

Eight cruises were carried out in SGB during June and September 2012, April, July, and October 2013, January and May 2014, and May 2015. The sampling locations are shown in Fig. 2. Duplicate samples of surface and bottom seawater were collected using 101 Niskin bottles, and then filled into $116 \mathrm{ml}$ glass bottles. After overflow of approximately 1.5- to 2-fold of bottle volume, $1 \mathrm{ml}$ of saturated solution of $\mathrm{HgCl}_{2}$ was added to inhibit microbial activity. The sample bottle was then immediately sealed with a butyl rubber stopper and an aluminum cap and stored upside down in a dark box (Zhang et al. 2008). All water samples were analyzed after return to the shore laboratory within $60 \mathrm{~d}$ of collection (Zhang et al. 2004). Salinity and seawater temperature were measured with a multi-parameter probe (WTW 350i), and wind speeds were measured with an anemometer at about $10 \mathrm{~m}$ above the sea surface.

To evaluate the $\mathrm{CH}_{4}$ input from potential terrestrial sources, water samples were collected from 4 rivers (Sanggan, $\mathrm{Ba}$, Shili, and $\mathrm{Gu}$ ) and 6 groundwater wells (GW1-GW6, Fig. 2) along the shoreline of SGB in June and September 2012, April, July, and October 2013, and January 2014. River water and groundwater were collected using a 51 plastic sampler, and the samples were processed as for seawater described above. 
Dissolved $\mathrm{CH}_{4}$ in seawater was measured using a gas-stripping method described by Zhang et al. (2004). After purging with high-purity $\mathrm{N}_{2}$, samples were passed through a drying tube with calcium chloride to remove water vapor. $\mathrm{CH}_{4}$ was then separated on a $3 \mathrm{~m} \times 3 \mathrm{~mm}$ i.d. stainless steel column packed with 80/100 mesh Porapak Q and measured with a gas chromatograph (Shimadzu, model GC14B) equipped with a flame ionization detector (FID) (Zhang et al. 2004). FID responses were calibrated using known volumes of $\mathrm{CH}_{4}$ standards $(2.05,4.22$, and $50.4 \mathrm{ppmV}$; Research Institute of China National Standard Materials). The FID response signal and $\mathrm{CH}_{4}$ concentration had a linear relationship, so a multi-point calibration method was used to determine $\mathrm{CH}_{4}$ concentration based on chromatographic peak areas. The precision of this method was about $3 \%$ (Zhang et al. 2004).

\section{Sediment sampling and incubation experiments}

$\mathrm{CH}_{4}$ emission from the sediments was measured by the closed chamber incubation method previously described by Sun et al. (2015), which was modified from Barnes \& Owens (1999). Sediment samples were collected by a box corer at different sampling stations (Fig. 1), and only samples with undisturbed sediment surfaces were used. At each station, 15 sediment cores were collected using plexiglass tubes (i.d. = $5 \mathrm{~cm}$, height $=30 \mathrm{~cm}$ ) and sealed using air-tight rubber bungs. After ambient bottom water was added carefully with no gas headspace, the core was capped with a plexiglass top with 2 sampling ports. All cores were placed in a water-filled tank held at ambient room temperature, and the overlying water was stirred by magnetic stirrers rotated at $60 \mathrm{rpm}$. Ten glass bottles filled with ambient bottom water were placed in the same tank as water column controls. Cores and bottled waters were incubated in the dark for $\sim 24$ to $48 \mathrm{~h}$. Overlying water samples $(56.5 \mathrm{ml})$ from 3 cores were collected each time at intervals of 4 to $8 \mathrm{~h}$ to measure $\mathrm{CH}_{4}$ concentration. At the same time, 2 bottled water samples were also treated with $0.5 \mathrm{ml}$ $\mathrm{HgCl}_{2}$ as a water column control. The $\mathrm{CH}_{4}$ concentrations of all samples were measured by the gas-stripping method described above. Sediment-water $\mathrm{CH}_{4}$ flux was estimated from the slope of the $\mathrm{CH}_{4}$ increase in the overlying water versus time. The discrepancy in the $\mathrm{CH}_{4}$ emission rate that resulted from differences between incubation and in situ temperatures was calibrated by the Arrhenius empirical equation as described by Aller et al. (1985) and Song et al. (2016).

\section{Water incubation experiments}

Time series incubation experiments were conducted to determine net $\mathrm{CH}_{4}$ production-oxidation rates and understand the potential production mechanism in April, July, and October 2013 and January, May, and September 2014. To test for the effects of methylated compounds on $\mathrm{CH}_{4}$ production, surface water samples were incubated with or without the addition of dimethylsulfoniopropionate (DMSP; final concentration $50 \mu \mathrm{M}$ ), or trimethylamine (final concentration $1 \mu \mathrm{M}$ ), or with added 2-bromoethane sulfonic acid (BES; final concentration $10 \mathrm{mM}$ ) to inhibit methanogenesis, and the $\mathrm{CH}_{4}$ concentrations were monitored for more than $9 \mathrm{~d}$ in October 2013. Seawater for incubation experiments was transferred from the 101 polyvinylchloride sampling bottles into clean polycarbonate carboys before the start of each experiment. DMSP, trimethylamine, or BES were added to the final concentration, and subsamples were transferred into $56.5 \mathrm{ml}$ glass serum bottles that were capped with gas-tight Teflon-lined silicone stoppers and crimp-sealed with aluminum caps. Subsamples with no added reagents were used as controls. The incubations were conducted at approximately in situ water temperatures $\left(3^{\circ} \mathrm{C}\right.$ for January, $10^{\circ} \mathrm{C}$ for April, $15^{\circ} \mathrm{C}$ for May, $26^{\circ} \mathrm{C}$ for July, $23^{\circ} \mathrm{C}$ for September, $18^{\circ} \mathrm{C}$ for October) under an approximately $12: 12 \mathrm{~h}$ light:dark cycle. Duplicate water samples were poisoned by addition of $0.5 \mathrm{ml}$ of saturated $\mathrm{HgCl}_{2}$ solution at 1 to $2 \mathrm{~d}$ intervals and analyzed for $\mathrm{CH}_{4}$ as described above. Two additional samples for dissolved oxygen (DO) were collected and measured using the Winkler titration method (Bryan et al. 1976). Net $\mathrm{CH}_{4}$ production-oxidation rates were estimated from the initial slope of the increase of $\mathrm{CH}_{4}$ over time.

\section{Saturation and flux calculation}

The saturation $(R, \%)$ and sea-to-air fluxes of $\mathrm{CH}_{4}$ $\left(F, \mu \mathrm{mol} \mathrm{m}{ }^{-2} \mathrm{~d}^{-1}\right)$ were calculated using the following equations:

$$
\begin{gathered}
R=C_{\mathrm{obs}} / C_{\mathrm{eq}} \times 100 \% \\
F=k_{\mathrm{w}}\left(C_{\mathrm{obs}}-C_{\mathrm{eq}}\right)
\end{gathered}
$$

where $C_{\text {obs }}$ is the observed concentration of dissolved $\mathrm{CH}_{4}$, and $\mathrm{C}_{\text {eq }}$ is the air-equilibrated seawater $\mathrm{CH}_{4}$ concentration calculated from the in situ temperature and salinity using the equation of Wiesenburg \& Guinasso (1979). Atmospheric $\mathrm{CH}_{4}$ was not measured during these cruises. Therefore, mean atmospheric 
$\mathrm{CH}_{4}$ mixing ratios of $1.896,1.901$, and $1.929 \mathrm{ppm}$ by volume (ppmv) at 3 observation stations near the coastal seas of China (NOAA Stns LLN, TAP, and SDZ) for 2012, 2013, and 2014, from the NOAA/ESRL Global Monitoring Division in situ program (www. esrl.noaa.gov/gmd), were used for calculations. We found that the variation of assumed atmospheric $\mathrm{CH}_{4}$ concentrations in the range of 1.85 to $1.95 \mathrm{ppmv}$ make differences less than $\pm 2 \%$ in the computed air-sea $\mathrm{CH}_{4}$ fluxes. Hence use of the annual mean atmospheric $\mathrm{CH}_{4}$ concentration from monitoring networks for the sea-air flux calculation will not introduce significant errors. $k_{\mathrm{w}}$ is the gas transfer coefficient in $\mathrm{cm} \mathrm{h}^{-1}$, which is a function of wind speed and Schmidt number $(\mathrm{Sc})$. Various empirical equations were employed to estimate $k$, among which the equations from Liss \& Merlivat (1986) and Wanninkhof (1992) were used most frequently and represent the estimation in a lower and higher level, respectively. Nightingale et al. (2000) proposed a gas exchange relationship that shows a dependence on wind speed, and the corresponding value lies near the median of extensive methods and models. Wanninkhof (2014) recently updated the most frequently used method of Wanninkhof (1992), and this update reflects advances that have occurred over the last 2 decades in quantifying the gas transfer coefficient. Hence the methods from Nightingale et al. (2000) and Wanninkhof (2014) (hereafter N2000 and W2014) were chosen to calculate air-sea fluxes in this study.

\section{RESULTS}

\section{Water column $\mathrm{CH}_{4}$ and other parameters}

Table 1 shows the temperature, salinity, and $\mathrm{CH}_{4}$ concentration in surface and bottom waters of SGB during the 8 cruises. Water temperature ranged from
3.1 to $23.2^{\circ} \mathrm{C}$, with the extremes in January and September. Salinity varied slightly, from 29.3 to $31.6 \mathrm{psu}$, with the lowest in September. DO in the water column ranged from 4.6 to $12.3 \mathrm{mg} \mathrm{l}^{-1}$ with an average of $10.2 \pm 2.6$ for June 2012, $6.3 \pm 0.8$ for September 2012, $9.8 \pm 0.8$ for April 2013, $9.1 \pm 1.3$ for July 2013, $10.5 \pm 1.9$ for January 2014, and $6.2 \pm 0.4 \mathrm{mg} \mathrm{l}^{-1}$ for May 2015. DO in the surface water is usually comparable or slightly higher than at the bottom. Suspended particulate matter (SPM) in surface and bottom waters, respectively, was $18.6 \pm 2.8$ (mean \pm SD) and $26.9 \pm 13.9 \mathrm{mg} \mathrm{l}^{-1}$ for September 2012, $13.6 \pm 9.1$ and $14.9 \pm 11.6$ for April 2013, $11.3 \pm 6.9$ and $37.6 \pm$ 26.8 for July $2013,14.1 \pm 5.7$ and $27.6 \pm 15.0$ for October 2013 , and $15.9 \pm 14.1$ and $13.5 \pm 12.6 \mathrm{mg} \mathrm{l}^{-1}$ for January 2014. Obvious high bottom SPM was observed during the period from July to October. $\mathrm{CH}_{4}$ concentrations in the water column ranged between 3.0 and $356 \mathrm{nM}$, and showed clear seasonal variation, with higher levels occurring in summer and autumn and lower levels in winter and early spring. $\mathrm{CH}_{4}$ concentrations in autumn were comparable to those in summer and about 7- to 8-fold higher than those in winter and spring. Bottom $\mathrm{CH}_{4}$ concentrations were higher than those at the surface during all cruises except in September 2012, during which surface $\mathrm{CH}_{4}$ was $50 \%$ higher than in bottom water together with the lowest salinity among all cruises.

\section{Geographical distributions of $\mathrm{CH}_{4}$ in SGB}

Fig. 3 shows the geographical distributions of temperature, salinity, and $\mathrm{CH}_{4}$ in surface waters of SGB measured during this study. Two cruises were carried out in spring (April 2013 and May 2015), during which the kelp thrived and the long kelp enhanced frictional effects in the upper layers and influenced the water exchange between the bay and the Yellow

Table 1. Water temperature $\left({ }^{\circ} \mathrm{C}\right)$, salinity (psu), and $\mathrm{CH}_{4}$ concentrations $(\mathrm{nM})$ in surface and bottom waters of Sanggou Bay, China, during 8 cruises. Mean $\pm \mathrm{SD}$

\begin{tabular}{|c|c|c|c|c|c|c|c|c|c|}
\hline \multirow{2}{*}{$\begin{array}{l}\text { Date } \\
\text { (yyyy-mm) }\end{array}$} & \multirow{2}{*}{ Station } & \multicolumn{2}{|c|}{ Temperature } & \multicolumn{2}{|c|}{ Salinity } & \multicolumn{2}{|c|}{ Surface $\mathrm{CH}_{4}$} & \multicolumn{2}{|c|}{ Bottom $\mathrm{CH}_{4}$} \\
\hline & & Surface & Bottom & Surface & Bottom & Range & Average & Range & Average \\
\hline 2014-01 & 21 & $3.5 \pm 1.1$ & $3.1 \pm 1.1$ & $31.3 \pm 0.1$ & $31.3 \pm 0.1$ & $4.3-10.1$ & $6.2 \pm 1.4$ & $4.3-19.4$ & $8.7 \pm 4.95$ \\
\hline 2013-04 & 20 & $7.7 \pm 1.2$ & $7.8 \pm 1.2$ & $31.6 \pm 0.2$ & $31.6 \pm 0.2$ & $5.2-10.1$ & $7.2 \pm 1.3$ & $5.6-10.6$ & $8.0 \pm 1.5$ \\
\hline 2014-05 & 10 & $13.8 \pm 2.2$ & $14.1 \pm 1.1$ & $31.3 \pm 0.4$ & $31.3 \pm 0.3$ & $3.0-24.9$ & $9.3 \pm 7.9$ & $3.0-29.5$ & $12.5 \pm 8.4$ \\
\hline 2015-05 & 21 & $14.2 \pm 2.4$ & $12.6 \pm 1.8$ & $31.5 \pm 0.2$ & $31.4 \pm 0.1$ & $5.4-43.4$ & $22.6 \pm 10.1$ & $5.3-46.7$ & $25.0 \pm 11.0$ \\
\hline $2012-06$ & 20 & $18.6 \pm 3.2$ & $17.3 \pm 2.1$ & $30.6 \pm 0.3$ & $30.4 \pm 0.2$ & $12.4-91.3$ & $38.3 \pm 21.9$ & $5.8-98.4$ & $43.9 \pm 27.9$ \\
\hline 2013-07 & 27 & $21.3 \pm 1.9$ & $18.4 \pm 0.8$ & $29.8 \pm 1.2$ & $30.4 \pm 0.1$ & $10.8-82.1$ & $53.0 \pm 17.3$ & $7.5-114$ & $75.9 \pm 23.4$ \\
\hline 2012-09 & 13 & $23.2 \pm 0.9$ & $22.3 \pm 1.0$ & $29.3 \pm 1.0$ & $29.8 \pm 0.7$ & $23.5-128$ & $53.8 \pm 33.5$ & $21.7-136$ & $35.5 \pm 32.8$ \\
\hline 2013-10 & 21 & $18.6 \pm 1.4$ & $18.6 \pm 0.9$ & $30.0 \pm 0.2$ & $29.9 \pm 0.1$ & $21.5-302$ & $63.8 \pm 59.5$ & $34.3-356$ & $99.6 \pm 81.4$ \\
\hline
\end{tabular}




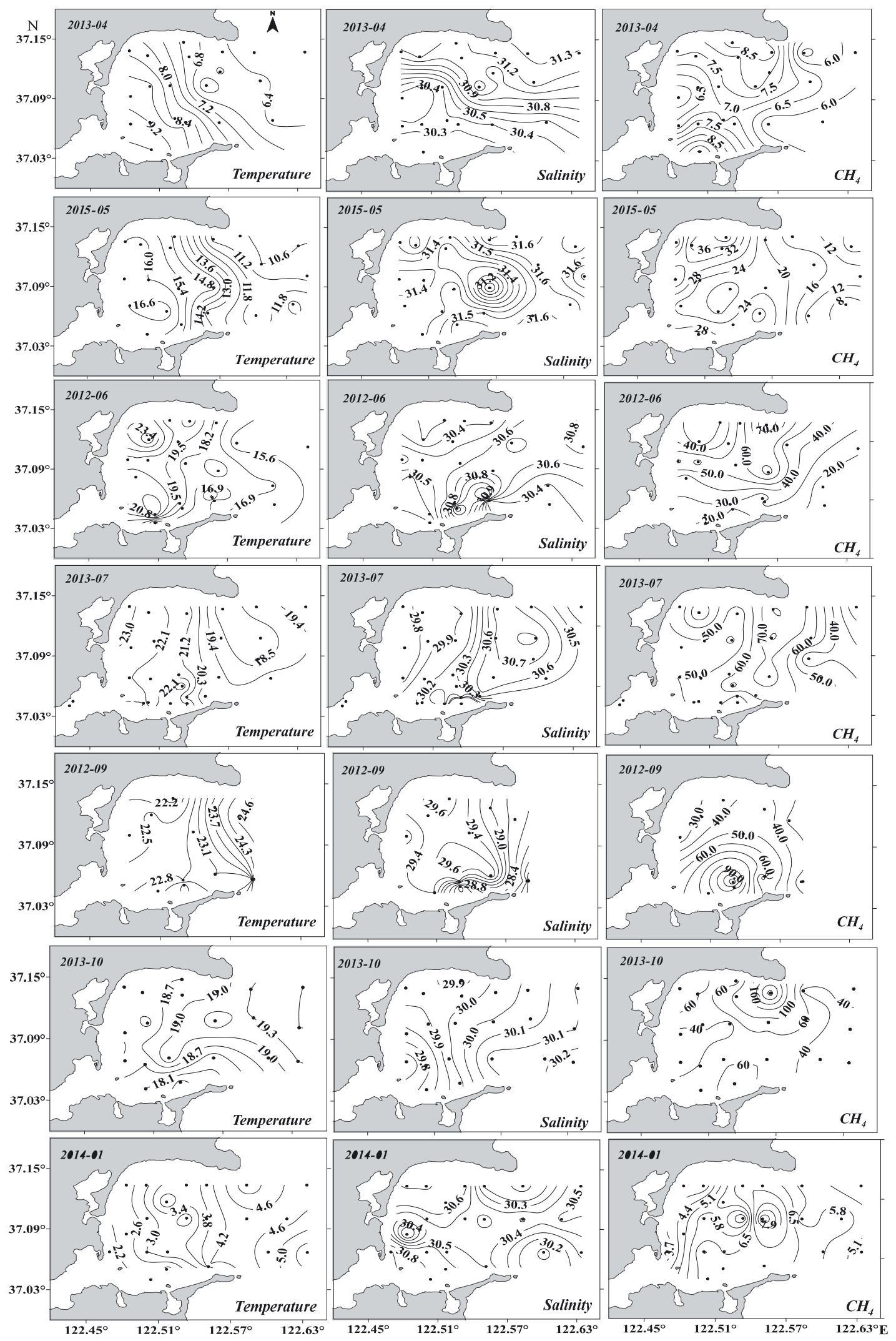

Fig. 3. Geographical distributions of water temperature $\left({ }^{\circ} \mathrm{C}\right)$, salinity, and $\mathrm{CH}_{4}$ concentration (nM) in surface waters of Sanggou Bay (SGB) during 2012 to 2015 (dates are yyyy-mm) 
Sea (Zeng et al. 2015). Surface water temperature was higher in May than in April and presented a similar trend, which decreased gradually from nearshore to offshore, and showed an obvious gradient. In contrast, surface salinity increased from nearshore to offshore in May, while it decreased gradually from the northeast to the southwest in April. Dissolved $\mathrm{CH}_{4}$ in April decreased gradually from the southwest and the northeast to the central bay, with concentrations ranging between 6 and $8 \mathrm{nM}$. In May, $\mathrm{CH}_{4}$ concentrations in the inner bay were higher than those in outer bay, with highest dissolved $\mathrm{CH}_{4}$ occurring in the northern part of the bay.

During summer cruises (June 2012 and July 2013), kelps had already been harvested, and water exchange with the Yellow Sea was not influenced by suspended kelp. Water temperature had a similar trend as in spring, i.e. decreasing from nearshore to offshore. Surface salinity varied in a narrow range (30.4-31.0) in June and increased slightly from the coast to the center of the bay, while in July, salinity increased gradually from the inner to the outer bay with low salinity $(<30)$ in nearly half of the bay. $\mathrm{CH}_{4}$ concentrations were much lower in June (mean $\pm \mathrm{SD}: 38.3 \pm 21.9 \mathrm{nM})$ than in July $(53.0 \pm 17.3 \mathrm{nM})$, and decreased gradually from the inner to the outer bay. In July, dissolved $\mathrm{CH}_{4}$ concentrations increased from about $50 \mathrm{nM}$ in the inner bay to $>70 \mathrm{nM}$ at the mouth of the bay, then decreased to $<40 \mathrm{nM}$ in the outer bay.

During autumn (September 2012 and October 2013), water temperature increased gradually from the inner to the outer bay, but the gradient was less pronounced. Salinity was relatively low $(<30)$ compared to other seasons due to heavy rainfall and freshwater input. In September, low salinity $(<29)$ together with high $\mathrm{CH}_{4}$ (>90 nM) was observed in the southern part of the bay. However, $\mathrm{CH}_{4}$ concentrations presented an opposite trend in October, with the highest value (>140 nM) measured in the northeastern part of the bay, while salinity increased gradually from inner to outer bay.

During winter (January 2014), the Bohai South Coast Current enters the bay from the north and flows out from the south through the west coast of the bay (Sun et al. 2007). Surface seawater temperature decreased gradually from the outer to the inner bay, while surface salinity (30.2-30.6) showed little variation over the whole bay. Dissolved $\mathrm{CH}_{4}$ concentrations in January were the lowest during the whole year, with highest $\mathrm{CH}_{4}(8 \mathrm{nM})$ occurring near the center of the bay. It then decreased rapidly seaward to $<4 \mathrm{nM}$ at the bay mouth.

\section{Riverine and groundwater input}

Rivers and groundwater are potential sources for dissolved $\mathrm{CH}_{4}$ in $\mathrm{SGB}$. $\mathrm{CH}_{4}$ concentrations in the main rivers around the bay are shown in Fig. 4, which ranged from 123 to $2190 \mathrm{nM}$ and were 1 to 2 orders of magnitude higher than those (3-356 nM) observed in the water column of the bay. Riverine $\mathrm{CH}_{4}$ also presented obvious spatial and seasonal variations. For example, lowest $\mathrm{CH}_{4}$ values usually occurred in winter, and the highest values occurred in summer and early fall for the smaller rivers (i.e. Sanggan, Shili, and Ba Rivers), while higher $\mathrm{CH}_{4}$ values occurred in winter and summer, and lower $\mathrm{CH}_{4}$ occurred in spring and late fall in the Gu River.

Considering that the runoff from the Sanggan, Shili, and Ba Rivers is limited and we lack discrete flow rate data for each river, we attributed $70 \%$ of the total runoff to the $\mathrm{Gu}$ River and $30 \%$ to the other rivers (Jiang et al. 2015). Riverine $\mathrm{CH}_{4}$ flux to the SGB was estimated to be $1.4 \times 10^{5} \mathrm{~mol} \mathrm{yr}^{-1}$, using the average $\mathrm{CH}_{4}$ concentrations in the Gu River (665 nM) and other small rivers (857 $\mathrm{nM})$, and mean annual runoff $\left(2.0 \times 10^{8} \mathrm{~m}^{3}\right)$.

Dissolved $\mathrm{CH}_{4}$ concentrations in groundwater ranged from 1.6 to $405 \mathrm{nM}$ and showed large spatial and temporal variations (Fig. 5). Groundwater near the mouth of the bay (GW4) had the highest $\mathrm{CH}_{4}$ concentrations (26.2-255 nM, mean $98.6 \mathrm{nM})$, and Stn GW1 had medium values (6.7-109 nM, mean $40.7 \mathrm{nM}$ ), while those in the other areas usually had low $\mathrm{CH}_{4}(<10 \mathrm{nM})$. For each region, lowest groundwater $\mathrm{CH}_{4}$ usually occurred in winter (January) and early spring (April), while the highest values all occurred in late summer (September). In general, $\mathrm{CH}_{4}$ concentrations in groundwater were much lower than those in rivers, but the submarine groundwater discharge to the SGB was $\sim 50$ times larger than river

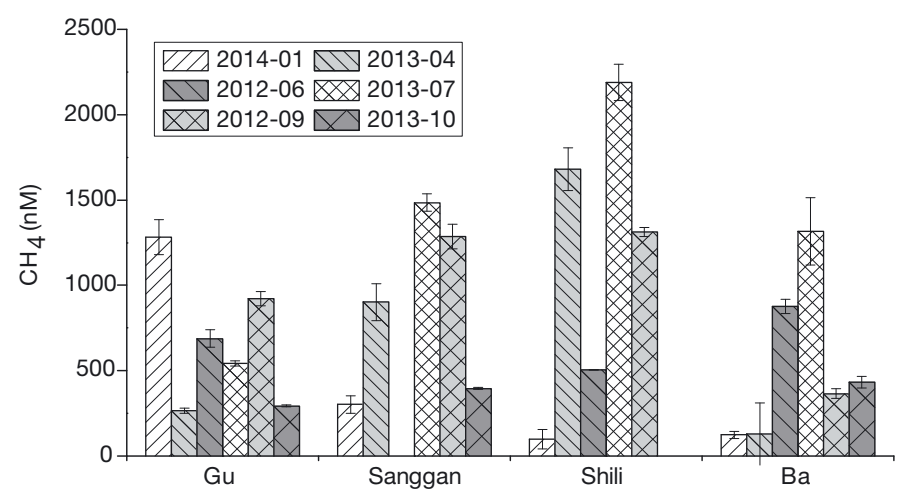

Fig. 4. $\mathrm{CH}_{4}$ concentrations (mean $\pm \mathrm{SD}$ ) in different rivers flowing into Sanggou Bay in different seasons and years (yyyy-mm) 
runoff, and estimated to be $(2.59-3.07) \times 10^{7} \mathrm{~m}^{3} \mathrm{~d}^{-1}$ based on the non-conservative inventory of ${ }^{226} \mathrm{Ra}$ and ${ }^{228} \mathrm{Ra}$ in the water column (Wang et al. 2014). Hence, we estimated the $\mathrm{CH}_{4}$ flux to the bay via the submarine groundwater by multiplying mean $\mathrm{CH}_{4}$ concentration $(40.2 \mathrm{nM})$ in the end-member well samples by the radium-derived mean submarine groundwater discharge $\left(2.83 \times 10^{7} \mathrm{~m}^{3} \mathrm{~d}^{-1}\right)$. It yielded a flux of $4.2 \times$ $10^{5} \mathrm{~mol} \mathrm{yr}^{-1}$, which was 3 times that of riverine $\mathrm{CH}_{4}$ flux.

\section{Sediment-water $\mathrm{CH}_{4}$ fluxes}

$\mathrm{CH}_{4}$ fluxes across the sediment-water interface were measured at Stns MC, ST1, and ST2 (Fig. 6), among which Stns MC and ST1 were located in the kelp and bivalve polyculture zone, and Stn ST2 was located in the oyster monoculture zone. Sedimentwater $\mathrm{CH}_{4}$ fluxes from Stn ST1 ranged from 0.73 to $1.65 \mu \mathrm{mol} \mathrm{m}{ }^{-2} \mathrm{~d}^{-1}$ with a mean $( \pm \mathrm{SD})$ of $1.19 \pm$

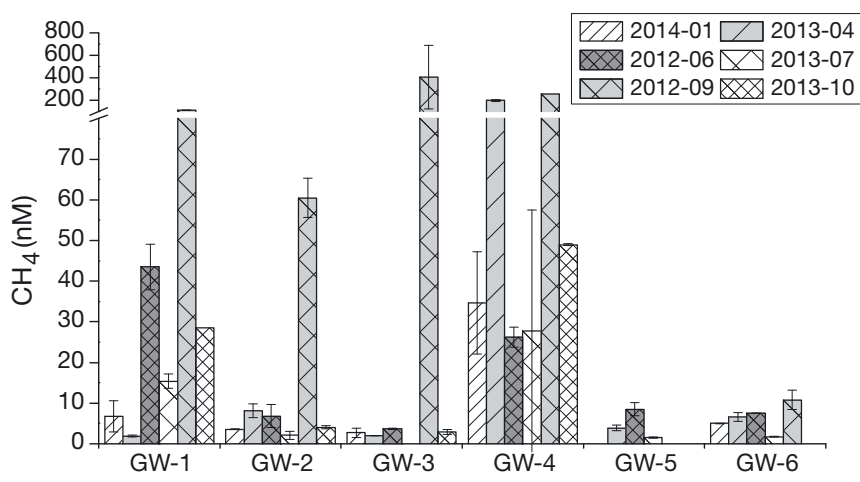

Fig. 5. $\mathrm{CH}_{4}$ concentrations in groundwater measured at 6 stations (GW1-GW6) along the shoreline of Sanggou Bay in different seasons and years (yyyy-mm)

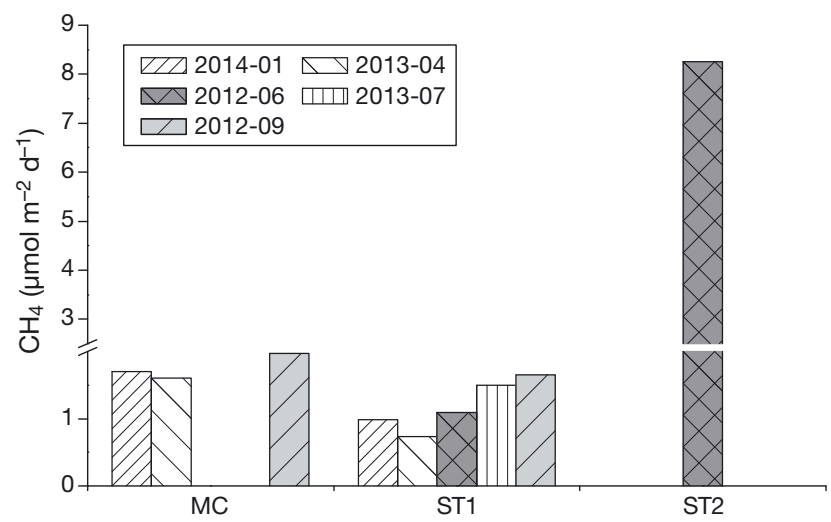

Fig. 6. Sediment-water $\mathrm{CH}_{4}$ fluxes $\left(\mu \mathrm{mol} \mathrm{m} \mathrm{m}^{-2} \mathrm{~d}^{-1}\right)$ at Stns MC, ST1, and ST2 in Sanggou Bay (see Fig. 2) in different seasons and years (yyyy-mm)
$0.38 \mu \mathrm{mol} \mathrm{m}{ }^{-2} \mathrm{~d}^{-1}$, which showed obvious seasonal variation and correlated well with bottom water temperature $\left(F=0.039 T+0.66, \mathrm{n}=5, \mathrm{r}^{2}=0.67\right)$. Sediment-water $\mathrm{CH}_{4}$ fluxes from Stn $\mathrm{MC}$ ranged from 1.60 to $1.97 \mu \mathrm{mol} \mathrm{m}{ }^{-2} \mathrm{~d}^{-1}$ with a mean of $1.76 \pm$ $0.19 \mu \mathrm{mol} \mathrm{m}{ }^{-2} \mathrm{~d}^{-1}$. Sediment-water $\mathrm{CH}_{4}$ fluxes from Stn ST1 $\left(1.19 \mu \mathrm{mol} \mathrm{m}^{-2} \mathrm{~d}^{-1}\right)$ was lower than that from Stn ST2 $\left(8.26 \mu \mathrm{mol} \mathrm{m}^{-2} \mathrm{~d}^{-1}\right)$ in June 2012. Although the sediment-water $\mathrm{CH}_{4}$ flux from the oyster culture zone was measured only during 1 cruise, considering the seasonal variation trend in the polyculture zone, it is reasonable to deduct this flux as an annual average value. Based on the total surface area (about $144 \mathrm{~km}^{2}$ ) (Zhang et al. 2009), average sedimentwater $\mathrm{CH}_{4}$ fluxes of $8.26 \mu \mathrm{mol} \mathrm{m}^{-2} \mathrm{~d}^{-1}$ (bivalve culture zone) and $1.48 \mu \mathrm{mol} \mathrm{m} \mathrm{m}^{-2} \mathrm{~d}^{-1}$ (polyculture zone), and assuming that the area ratio of the 2 culture zones is 1:1, annual $\mathrm{CH}_{4}$ emission from sediments of SGB was estimated to be about $2.6 \times 10^{5} \mathrm{~mol}$.

\section{Water column methane production-oxidation}

Net water column $\mathrm{CH}_{4}$ production-oxidation rates $\left(\mathrm{CH}_{4}\right.$ formation- $\mathrm{CH}_{4}$ oxidation) were estimated to be $0.25,0.41,0.19,0.39$, and $0.31 \mathrm{nM} \mathrm{d}^{-1}$ for Stn $\mathrm{MC}$ in April and July 2013 and January, May, and September 2014, which showed significant seasonal variation and correlated well with temperature $(R=0.01 T$ $+0.19, \mathrm{n}=5, \mathrm{r}^{2}=0.70$ ). Net water column $\mathrm{CH}_{4}$ production-oxidation rates were 0.28 and $0.67 \mathrm{nM}$ $\mathrm{d}^{-1}$ for Stns ST2 and SG-3 in September 2014. If we take the mean value of $0.42 \mathrm{nM} \mathrm{d}^{-1}$ at these stations as the net $\mathrm{CH}_{4}$ production rate in the water column, together with the area of $144 \mathrm{~km}^{2}$ and a mean water depth of $7.5 \mathrm{~m}$, total net $\mathrm{CH}_{4}$ productionoxidation in the water column was estimated to be $1.7 \times 10^{5} \mathrm{~mol} \mathrm{yr}^{-1}$.

\section{Surface $\mathrm{CH}_{4}$ saturation and sea-to-air fluxes}

$\mathrm{CH}_{4}$ saturation in the surface waters of SGB ranged from 202 to $2734 \%$ (Fig. 7), with great spatial and temporal variation. Average saturation was higher in autumn and summer than in spring and winter. In general, the surface waters of SGB were all over-saturated with $\mathrm{CH}_{4}$, except for a few stations during winter. Thus, SGB is a net source of atmospheric $\mathrm{CH}_{4}$.

Sea-to-air $\mathrm{CH}_{4}$ fluxes calculated with the W2014 equation ranged from 2.1 to $123 \mu \mathrm{mol} \mathrm{m}{ }^{-2} \mathrm{~d}^{-1}$ with a mean of $48.2 \mu \mathrm{mol} \mathrm{m}{ }^{-2} \mathrm{~d}^{-1}$, which was comparable to the results from the $\mathrm{N} 2000$ equation $(2.3-126 \mu \mathrm{mol}$ 


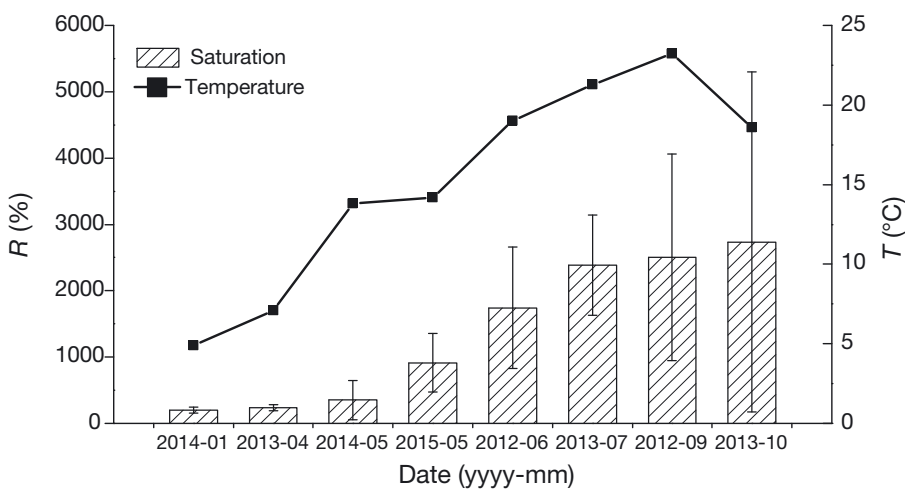

Fig. 7. $\mathrm{CH}_{4}$ saturation $(R, \%$; mean $\pm \mathrm{SD})$ and water temperature $\left(T,{ }^{\circ} \mathrm{C}\right)$ in surface waters of Sanggou Bay

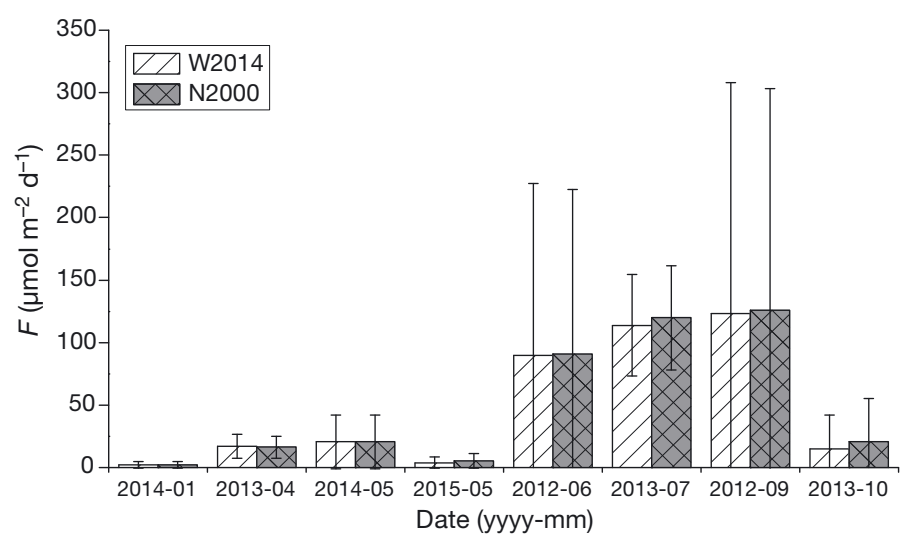

Fig. 8. Seasonal variation of air-sea $\mathrm{CH}_{4}$ fluxes $\left(F, \mu \mathrm{mol} \mathrm{m}{ }^{-2}\right.$ $\mathrm{d}^{-1}$; mean $\pm \mathrm{SD}$ ) in Sanggou Bay, estimated using 2 different equations (W2014 and N2000); see 'Materials and methods' for details

$\mathrm{m}^{-2} \mathrm{~d}^{-1}$ with a mean of $50.3 \mu \mathrm{mol} \mathrm{m} \mathrm{m}^{-2} \mathrm{~d}^{-1}$; Fig. 8). $\mathrm{CH}_{4}$ fluxes showed clear seasonal variation, with those in early autumn (September) comparable to those in summer (July and June), and more than 8-fold higher than those in spring (April) and autumn (October); the lowest values occurred in winter. In addition, we estimated the $\mathrm{CH}_{4}$ emission from SGB to be $2.5 \times$ $10^{6} \mathrm{~mol} \mathrm{yr}^{-1}$ based on the annual mean atmospheric $\mathrm{CH}_{4}$ flux (48.2 $\mu \mathrm{mol} \mathrm{m} \mathrm{m}^{-2} \mathrm{~d}^{-1}$ ) from this study and the area of SGB $\left(144 \mathrm{~km}^{2}\right)$.

\section{$\mathrm{CH}_{4}$ exchange with the Yellow Sea}

Considering that dissolved $\mathrm{CH}_{4}$ in $\mathrm{SGB}$ was much higher than in the adjacent Yellow Sea, water exchange with the Yellow Sea should cause net loss of $\mathrm{CH}_{4}$ from the bay. Aquaculture activities may influence water exchange between SGB and the Yellow Sea; however, suspended kelp culture mainly changed the spatial pattern of the tidal flux but not the tidal prism (Zeng et al. 2015). Jiang et al. (2015) estimated the annual water exchange volume to be about $8.3 \times$ $10^{10} \mathrm{~m}^{3}$. $\mathrm{CH}_{4}$ concentrations gradients between the inner and outer bay were 3.6 nM for September 2012, 1.5, 11.9, and 40.7 nM for April, July, and October 2013, and 0.9 nM for January 2014, respectively. During the kelp seeding to harvesting period (November to May), the $\mathrm{CH}_{4}$ concentration gradient (mean: $1.2 \mathrm{nM}$ ) was lower than during the non-aquaculture period (mean: $18.7 \mathrm{nM}$ ). Hence, based on the annual mean observed $\mathrm{CH}_{4}$ concentration gradient between the inner and outer bay (10.0 nM), and the annual water exchange volume of the bay $\left(8.3 \times 10^{10} \mathrm{~m}^{3}\right)$, we estimated the $\mathrm{CH}_{4}$ flux exported out of the bay to be $8.8 \times 10^{5} \mathrm{~mol} \mathrm{yr}^{-1}$.

\section{DISCUSSION}

\section{Comparison with previous research}

Previous studies have reported $\mathrm{CH}_{4}$ concentrations for some bays, estuaries, and coastal and shelf areas of northern China (Table 2). Average $\mathrm{CH}_{4}$ concentrations in SGB during the corresponding seasons were lower than those reported for the adjacent Rushan Bay (mean \pm SD: $59.9 \pm 7.8$ nM, May 2007; Wang et al. 2008), Dalian Bay (59.4 \pm 82.0 nM, January 2010; $56.0 \pm 69.4$ nM, November 2009; Wang et al. 2011), and Jiaozhou Bay (137 \pm $224 \mathrm{nM}$ for August 2003 and $34.8 \pm 75.5$ for December 2003; Zhang et al. 2007), but obviously higher than the Yellow River estuary (3.9-14.3 nM; Gu et al. 2011) and Changjiang estuary (7.95 $\pm 5.24 \mathrm{nM}$; Zhang et al. 2008). $\mathrm{CH}_{4}$ concentrations of SGB were 2- to 10-fold of those in the adjacent marginal shelf sea, i.e. the Yellow Sea (3.4-12.0 nM; Zhang et al. 2004, Yang et al. 2010, Ye et al. 2016).

The estimated atmospheric $\mathrm{CH}_{4}$ fluxes from the SGB in this study were close to those from Jiaozhou Bay (Zhang et al. 2007) and Dalian Bay (Wang et al. 2011), and slightly higher than those from some estuaries, e.g. the Changjiang estuary (Zhang et al. 2008). However, $\mathrm{CH}_{4}$ fluxes from SGB were far higher than those from shelf areas, e.g. 2-fold higher than those from the adjacent North Yellow Sea during Spring (April), and 5 times higher than during winter (January) and summer (July for SGB, August for North Yellow Sea), respectively, but comparable to those from the adjacent North Yellow Sea during October (Yang et al. 2010). Hence SGB is a hot spot of $\mathrm{CH}_{4}$ emissions to the atmosphere. 
Table 2. Compilation of surface concentrations and sea-to-air fluxes of $\mathrm{CH}_{4}$ in different coastal areas of China (see Fig. 2 for station locations). Data are mean \pm SD

\begin{tabular}{|c|c|c|c|c|c|}
\hline Sea area & Date & Sampling station & $\mathrm{CH}_{4}(\mathrm{nM})$ & Flux $\left(\mu \mathrm{mol} \mathrm{m} \mathrm{m}^{-2} \mathrm{~d}^{-1}\right)$ & Reference \\
\hline Jiaozhou Bay & $\begin{array}{l}\text { Aug } 2003 \\
\text { Dec } 2003\end{array}$ & $\begin{array}{l}16 \\
14\end{array}$ & $\begin{array}{c}137 \pm 224 \\
34.8 \pm 75.5\end{array}$ & $\begin{array}{c}132 \pm 220 \\
36.9 \pm 87.3\end{array}$ & $\begin{array}{l}\text { Zhang et al. (2007) } \\
\text { Zhang et al. (2007) }\end{array}$ \\
\hline Rushan Bay & May 2007 & 8 & $59.90 \pm 7.75$ & - & Wang et al. (2008) \\
\hline Dalian Bay & $\begin{array}{l}\text { Jan } 2010 \\
\text { Nov } 2009\end{array}$ & $\begin{array}{l}17 \\
17\end{array}$ & $\begin{array}{l}59.41 \pm 81.97 \\
56.01 \pm 69.39\end{array}$ & $\begin{aligned} 133.07 & \pm 193.37^{\mathrm{a}}, 286.96 \pm 416.98^{\mathrm{b}} \\
52.88 & \pm 68.42^{\mathrm{a}}, 113.46 \pm 146.82^{\mathrm{b}}\end{aligned}$ & $\begin{array}{l}\text { Wang et al. (2011) } \\
\text { Wang et al. (2011) }\end{array}$ \\
\hline Yellow River estuary & Jun 2009 & 28 & $3.9-14.3$ & $7.2^{\mathrm{a}}, 14.2^{\mathrm{b}}$ & Gu et al. (2011) \\
\hline $\begin{array}{l}\text { Changjiang estuary } \\
\text { East China Sea }\end{array}$ & $\begin{array}{l}\text { Dec } 2004 \\
\text { Apr } 2001 \\
\text { Aug } 2013\end{array}$ & $\begin{array}{l}10 \\
29 \\
65\end{array}$ & $\begin{array}{l}7.95 \pm 5.24 \\
3.24 \pm 0.59 \\
6.26 \pm 4.96\end{array}$ & $\begin{array}{c}21.1 \pm 9.6^{\mathrm{a}}, 41.1 \pm 18.7^{\mathrm{b}} \\
1.63 \pm 1.67^{\mathrm{a}}, 2.77 \pm 2.71^{\mathrm{b}} \\
6.5 \pm 7.4^{\mathrm{a}}, 11.5 \pm 111.9^{\mathrm{b}}\end{array}$ & $\begin{array}{l}\text { Zhang et al. (2008) } \\
\text { Zhang et al. (2004) } \\
\text { Ye et al. (2016) }\end{array}$ \\
\hline Bohai Sea & Aug 2008 & 28 & $5.87 \pm 2.02$ & $3.1 \pm 1.6^{\mathrm{a}}, 8.1 \pm 4.2^{\mathrm{b}}$ & Li et al. (2010) \\
\hline North Yellow Sea & $\begin{array}{l}\text { Jan } 2007 \\
\text { Aug } 2007 \\
\text { Apr } 2007 \\
\text { Oct } 2006\end{array}$ & $\begin{array}{l}78 \\
76 \\
59 \\
80\end{array}$ & $\begin{array}{r}3.40 \pm 0.58 \\
6.43 \pm 2.52 \\
5.70 \pm 3.50 \\
12.02 \pm 7.51\end{array}$ & $\begin{array}{c}0.2 \pm 1.0^{\mathrm{a}}, 0.4 \pm 1.7^{\mathrm{b}} \\
4.2 \pm 4.7^{\mathrm{a}}, 6.9 \pm 7.3^{\mathrm{b}} \\
11.8 \pm 10.2^{\mathrm{a}}, 21.1 \pm 16.4^{\mathrm{b}} \\
8.5 \pm 12.7^{\mathrm{a}}, 14.6 \pm 22.3^{\mathrm{b}}\end{array}$ & $\begin{array}{l}\text { Yang et al. (2010) } \\
\text { Yang et al. (2010) } \\
\text { Yang et al. (2010) } \\
\text { Yang et al. (2010) }\end{array}$ \\
\hline Yellow Sea & Mar-Apr 2001 & 14 & $3.43 \pm 0.23$ & $0.81 \pm 0.50^{\mathrm{a}}, 1.33 \pm 0.76^{\mathrm{b}}$ & Zhang et al. (2004) \\
\hline Yellow and East China Seas & $\begin{array}{l}\text { Aug } 2011 \\
\text { Oct } 2011 \\
\text { Dec } 2011\end{array}$ & $\begin{array}{l}38 \\
55 \\
59\end{array}$ & $\begin{array}{l}8.21 \pm 6.02 \\
5.03 \pm 1.68 \\
4.07 \pm 0.63\end{array}$ & $\begin{array}{c}16.98 \pm 21.40^{\mathrm{c}}, 17.65 \pm 21.72^{\mathrm{d}} \\
9.88 \pm 9.97^{\mathrm{c}}, 9.87 \pm 9.61^{\mathrm{d}} \\
6.82 \pm 6.86^{\mathrm{c}}, 6.64 \pm 6.44^{\mathrm{d}}\end{array}$ & $\begin{array}{l}\text { Sun et al. (2015) } \\
\text { Sun et al. (2015) } \\
\text { Sun et al. (2015) }\end{array}$ \\
\hline \multicolumn{6}{|c|}{$\begin{array}{l}{ }^{\mathrm{a}} k_{\mathrm{w}} \text { was estimated by the LM86 equation (Liss \& Herlivat 1986) } \\
{ }^{\mathrm{b}} k_{\mathrm{w}} \text { was estimated by the W92 equation (Wanninkhoft 1992) } \\
{ }^{\mathrm{c}} k_{\mathrm{w}} \text { was estimated by the W2014 equation (see 'Materials and methods' for details) } \\
{ }^{\mathrm{d}} k_{\mathrm{w}} \text { was estimated by the N2000 equation (see 'Materials and methods' for details) }\end{array}$} \\
\hline
\end{tabular}

\section{Factors influencing spatial and temporal distribution of $\mathrm{CH}_{4}$ in SGB}

The concentration, saturation, water column production, and sediment-water fluxes of $\mathrm{CH}_{4}$ in SGB all had obvious seasonal variation and were closely related to water temperature. Mean water column $\mathrm{CH}_{4}$ concentrations and saturations during different cruises correlated positively with mean water temperature $\left(\mathrm{CH}_{4}\right.$ conc. $=2.33 T-4.70, \mathrm{r}^{2}=0.93, \mathrm{n}=11$, $\mathrm{p}<0.0001 ; R\left(\mathrm{CH}_{4}\right)=124.8 T-380.4, \mathrm{r}^{2}=0.8 \mathrm{n}=7, \mathrm{p}<$ 0.008 ). This is consistent with the positive correlations observed for net water column $\mathrm{CH}_{4}$ productionoxidation rates at $\operatorname{Stn} \mathrm{MC}\left(R=0.01 T+0.19, \mathrm{n}=5, \mathrm{r}^{2}=\right.$ $0.82, \mathrm{p}<0.09$ ) and sediment-water $\mathrm{CH}_{4}$ fluxes at Stn ST1 $\left(F=0.039 T+0.66, \mathrm{n}=5, \mathrm{r}^{2}=0.82, \mathrm{p}<0.09\right)$, which showed that $\mathrm{CH}_{4}$ production rates in both water column and sediments increase with rising temperature. Temperature mainly controls the organic matter decomposition and the activity of methanogenesis, and the rising temperature may increase the relative abundance and diversity of methanogenic communities (Metje \& Frenzel 2005, Høj et al. 2008). Yvon-Durocher et al. (2014) also reported seasonal variation in $\mathrm{CH}_{4}$ emissions from diverse ecosystems using meta-analysis, and showed that $\mathrm{CH}_{4}$ emissions increased significantly with seasonal increases in temperature. Hence our results suggest that water temperature plays a significant role in regulating the seasonal variation of $\mathrm{CH}_{4}$ in SGB.

Although the salinity of SGB only showed a slight fluctuation throughout the year, mean water column $\mathrm{CH}_{4}$ concentrations during different cruises correlated negatively with mean salinity $(S)\left(\mathrm{CH}_{4}\right.$ conc. = $\left.-0.33 S+5.43, \mathrm{r}^{2}=0.94, \mathrm{n}=11, \mathrm{p}<0.001\right)$, suggesting that terrestrial input (i.e. rivers and groundwater) also play a role in the seasonal variation of $\mathrm{CH}_{4}$ in the bay. In general, rivers and groundwater are primary routes for delivery of dissolved and particulate carbon and nutrients from land to coastal areas, and they are usually supersaturated with $\mathrm{CH}_{4}$ (Taniguchi et al. 2002, Striegl et al. 2012). Observed $\mathrm{CH}_{4}$ (123.3 to $2189.7 \mathrm{nM}$ ) in rivers around SGB are within the $\mathrm{CH}_{4}$ range (5-5000 nM) reported for rivers worldwide (de Angelis \& Lilley 1987, Upstill-Goddard et al. 2000) and much higher than those in the water column of the bay. Especially during the wet seasons (summer and early autumn), high discharges of river water and groundwater with rich $\mathrm{CH}_{4}$ enter the bay, affecting its spatial distribution. For example, observed surface $\mathrm{CH}_{4}$ in the bay was $50 \%$ higher than that in bottom water in September 2012 together 
with the lowest salinity (Table 1), while $\mathrm{CH}_{4}$ concentrations were usually higher at the bottom than at the surface during other cruises.

$\mathrm{CH}_{4}$ distribution in SGB may also be influenced by aquaculture activities. The bay is extensively used for culture of macroalgae and shellfish. Previous studies showed that $\mathrm{CH}_{4}$ can be produced in anaerobic microenvironments of SPM and digestive tracts of zooplankton and fish in oxygenic surface water (Marty 1993, Karl \&Tilbrook 1994). Obvious high bottom SPM was observed during the shellfish culture period from July to October. Dense populations of bivalve shellfish (i.e. scallop and oyster) in shallow water can produce a large amount of feces and pseudo-feces, hence the digestive tract of shellfish and their waste provide favorable environments for potential water column methanogenesis. Suspended shellfish culture also accelerates biodeposition and results in sediments with rich organic matter and high microbial activity (Green et al. 2012), which in turn enhances rates of anaerobic decomposition of organic matter and lead to high $\mathrm{CH}_{4}$ production in the sediment (Nizzoli et al. 2006, Jiang et al. 2015). Due to the sediment release, bottom $\mathrm{CH}_{4}$ concentrations in SGB were usually higher than those at the surface, especially in the culture zones with bivalve shellfish in summer (Fig. 9). For example, we observed $\mathrm{CH}_{4}$ concentrations at Stn ST2 in the oyster culture zone to be $4.0 \mathrm{nM}$ at the surface $(0 \mathrm{~m}), 3.8 \mathrm{nM}$ at $2 \mathrm{~m}, 5.9 \mathrm{nM}$ at $4 \mathrm{~m}$, and $12.0 \mathrm{nM}$ at the bottom $(6 \mathrm{~m})$ in May 2014. We also observed significant high sediment-water $\mathrm{CH}_{4}$ fluxes in the oyster culture zone $\left(8.26 \mu \mathrm{mol} \mathrm{m} \mathrm{m}^{-2} \mathrm{~d}^{-1}\right)$ compared to the polyculture zone $\left(1.09 \mu \mathrm{mol} \mathrm{m}{ }^{-2} \mathrm{~d}^{-1}\right)$ in June 2012. Green et al. (2012) observed greater $\mathrm{CH}_{4}$ emissions from the sediment in areas that had the highest cover of oysters compared to areas with medium cover. They attributed this to more $\mathrm{CH}_{4}$ produced by the reduction of $\mathrm{CO}_{2}$ and the stimulation by the 'priming effect,' whereby the addition of fresh labile organic matter (such as from oyster biodeposits) temporarily stimulates microbial decomposition, including that of older, buried, recalcitrant organic matter (Green et al. 2012).

Recent research has shown that under certain nutrient-limited conditions, a variety of methyl-rich organic phosphorus or sulfur compounds are likely to be utilized by microorganism and serve as precursors of $\mathrm{CH}_{4}$ production in aerobic surface waters (Damm et al. 2008, Karl et al. 2008, Zindler et al. 2013). Integrated multi-trophic aquaculture in SGB can enhance the recycling of organic matter and nutrients and provide favorable conditions for aerobic $\mathrm{CH}_{4}$ production. Bivalve shellfish ingest algae, POM, bac-
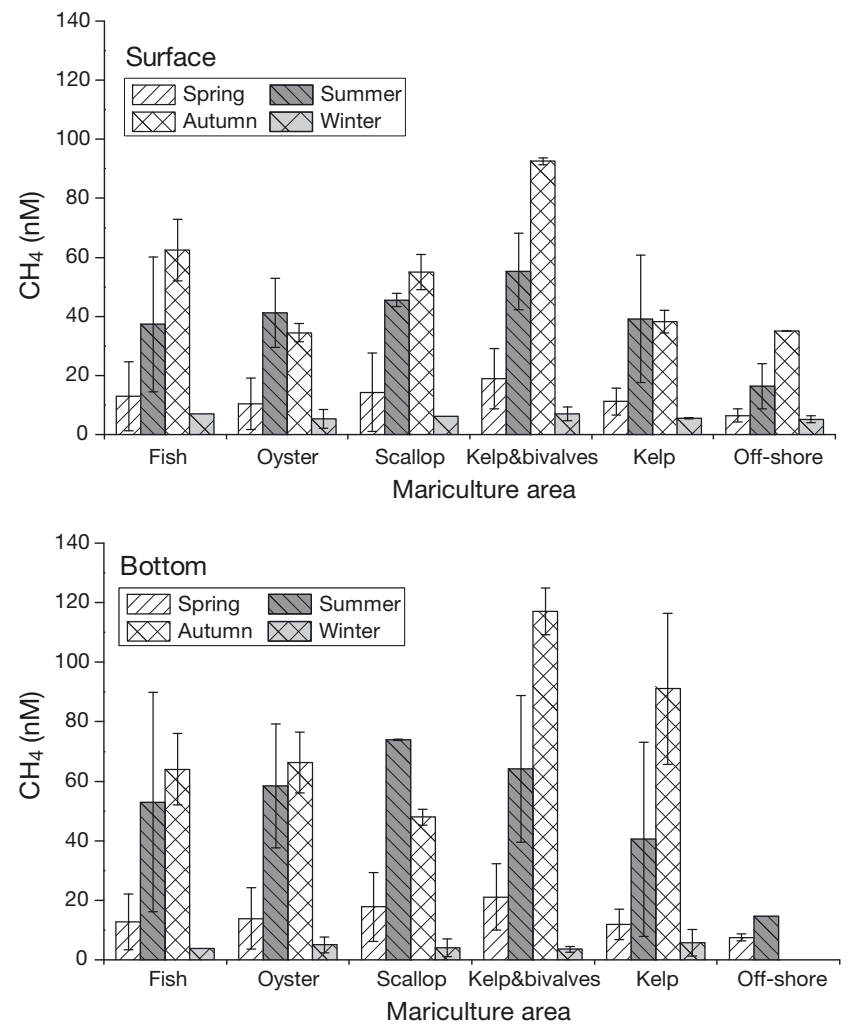

Fig. 9. Comparison of seasonal mean $( \pm \mathrm{SD}) \mathrm{CH}_{4}$ concentrations in surface and bottom waters in different culture areas of Sanggou Bay

teria, and other micro-organisms, while kelp absorbs organic and inorganic wastes from the shellfish (Fang et al. 1996). Commonly cultivated seaweeds (Gracilaria lemaneiformis and Laminaria japonica) in SGB have a high nutrient uptake efficiency (Mao et al. 2009, Xu et al. 2011) and may lead to nitrogen and phosphorus limitation in spring as well as phosphorus limitation in summer (Zhang et al. 2010), which in turn implies a potential formation of $\mathrm{CH}_{4}$ from methyl-rich organic phosphorus or sulfur compounds (Damm et al. 2008, Karl et al. 2008, Zindler et al. 2013). DMSP can be produced by macroalgae, and grazing by bivalves appears to facilitate the release of DMSP from kelp (Smit et al. 2007). Hence the water column in polyculture zones may contain higher levels of DMSP and enhance the production of $\mathrm{CH}_{4}$. Seasonal variation in mean $\mathrm{CH}_{4}$ in different mariculture areas of SGB support this hypothesis and show that higher surface $\mathrm{CH}_{4}$ concentrations usually occur in the polyculture areas of kelp and bivalve shellfish (Fig. 9). We also observed a highly significant and rapid increase in $\mathrm{CH}_{4}$ during incubations with DMSP spikes in October 2013 (Fig. 10). During the incubations, $\mathrm{CH}_{4}$ concentration increased sharply by more than 60 -fold and reached $460 \mathrm{nM}$ on Day 3.5, then decreased 


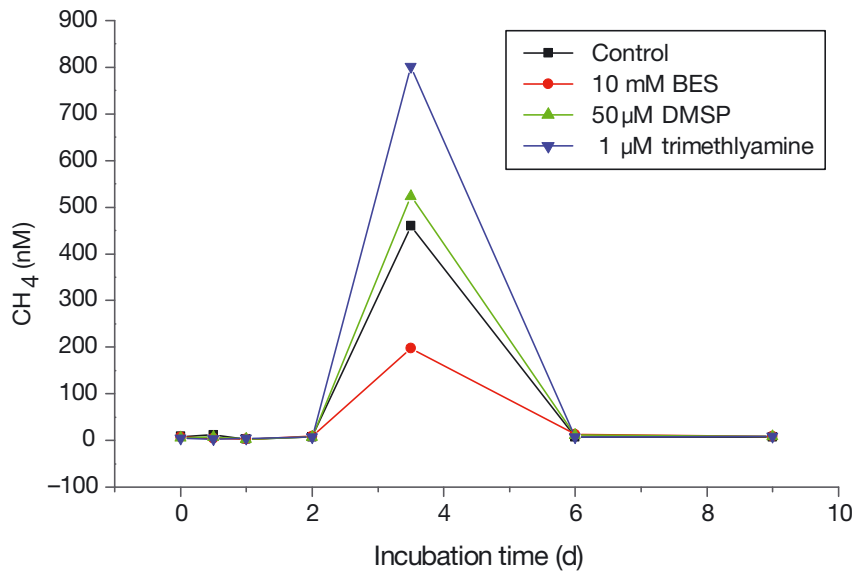

Fig. 10. $\mathrm{CH}_{4}$ time series incubation experiments at Station MC (see Fig. 2) during October 2013. BES: 2-bromoethane sulfonic acid, DMSP: dimethylsulfoniopropionate

sharply to the initial concentration around $7 \mathrm{nM}$. The addition of $10 \mu \mathrm{M}$ BES reduced the $\mathrm{CH}_{4}$ production by more than half, while the addition of $50 \mu \mathrm{M}$ DMSP and $1 \mu \mathrm{M}$ trimethylamine significantly enhanced $\mathrm{CH}_{4}$ production. During all of these incubations, DO in the bottles ranged from 5 to $8 \mathrm{mg} \mathrm{l}^{-1}$, suggesting that $\mathrm{CH}_{4}$ might be produced under aerobic conditions with the degradation of methylated compounds such as DMSP and trimethylamine in the water column in SGB.

\section{Preliminary $\mathrm{CH}_{4}$ budget and its implication}

In order to understand the contributions of different sources and sinks to dissolved $\mathrm{CH}_{4}$ in SGB, a preliminary $\mathrm{CH}_{4}$ budget was constructed, although there are still great uncertainties in the estimate of each term. Considering that the sea-air flux values from W2014 and N2000 were quite similar, we took the results estimated by W2014 for the budget estimation. From the budget (Fig. 11), we can see that the groundwater input $\left(4.2 \times 10^{5} \mathrm{~mol} \mathrm{yr}^{-1}\right)$ was the largest quantified $\mathrm{CH}_{4}$ source, followed by sediment

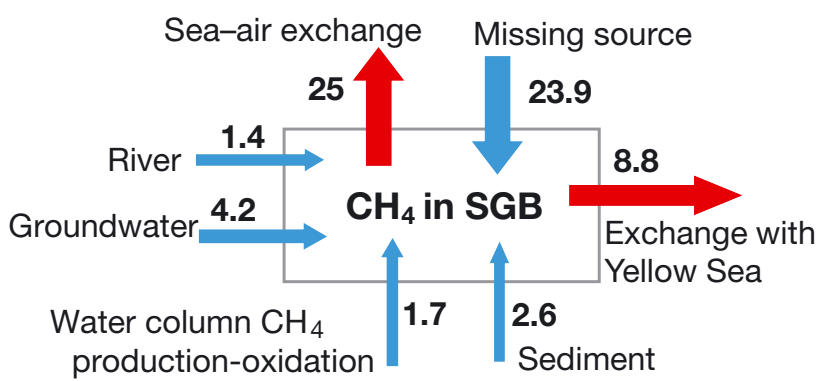

Fig. 11. Preliminary $\mathrm{CH}_{4}$ budget $\left(10^{5} \mathrm{~mol} \mathrm{yr}^{-1}\right)$ estimation for Sanggou Bay (SGB) release $\left(2.6 \times 10^{5} \mathrm{~mol} \mathrm{yr}^{-1}\right)$ and riverine input $(1.4 \times$ $\left.10^{5} \mathrm{~mol} \mathrm{yr}^{-1}\right)$, while sea-to-air release $\left(2.5 \times 10^{6} \mathrm{~mol}\right.$ $\left.\mathrm{yr}^{-1}\right)$ and export from the bay to the Yellow Sea $(8.8 \times$ $10^{5} \mathrm{~mol} \mathrm{yr}^{-1}$ ) were the dominant sinks for $\mathrm{CH}_{4}$ in SGB. Net water column production-oxidation was estimated preliminarily to produce $1.7 \times 10^{5} \mathrm{~mol} \mathrm{CH}_{4}$ $\mathrm{yr}^{-1}$. However, there is still a large imbalance between the sources and sinks of methane in the water column of SGB, with an apparent missing source of $2.4 \times 10^{6} \mathrm{~mol} \mathrm{yr}^{-1}$ needed to balance the budget, although this value might be overestimated due to the propagation of the errors in the other terms in the budget.

Because of the large spatial and temporal variations in $\mathrm{CH}_{4}$ concentrations in the groundwater samples, our ability to provide an accurate estimate for the $\mathrm{CH}_{4}$ flux via submarine groundwater discharge is rather limited due to the small number of groundwater end-member samples used in the calculation $(n=6)$ and lack of seasonal variation in groundwater fluxes. Hence the source item of groundwater may have large uncertainties.

Previous studies have demonstrated that sediments are a significant $\mathrm{CH}_{4}$ source for bays and coastal waters (Sansone et al. 1998, Ferrón et al. 2010). Ferrón et al. (2010) found that benthic $\mathrm{CH}_{4}$ fluxes from the shelf of the Gulf of Cádiz ranged from 0.5 to 24.1 $\mu \mathrm{mol} \mathrm{m} \mathrm{m}^{-2} \mathrm{~d}^{-1}$ with an average of $5 \pm 6 \mu \mathrm{mol} \mathrm{m} \mathrm{m}^{-2} \mathrm{~d}^{-1}$ using benthic chambers. Sansone et al. (1998) reported that $\mathrm{CH}_{4}$ benthic fluxes from Tomales Bay ranged from 0.4 to $16 \mu \mathrm{mol} \mathrm{m}{ }^{-2} \mathrm{~d}^{-1}$ with an average of 5.5 and $2.5 \mu \mathrm{mol} \mathrm{m} \mathrm{m}^{-2} \mathrm{~d}^{-1}$ for summer and winter, respectively. These results are comparable to or slightly higher than our results $\left(0.7-8.3 \mu \mathrm{mol} \mathrm{m}{ }^{-2} \mathrm{~d}^{-1}\right)$ for SGB. However, given the high rates of labile organic matter loading in SGB, this strongly indicates that the fluxes assessed during the sediment incubations in this study might be underestimated. The most influential factors for this underestimation are likely to be an insufficient number of sampling stations and the ex situ sediment incubation method we used. Sediment-water $\mathrm{CH}_{4}$ fluxes from SGB showed large spatial variation, although we only measured benthic fluxes at 3 stations and did not measure benthic fluxes from eelgrass beds in the southern region of SGB near Chudao. Previous studies showed that $\mathrm{CH}_{4}$ benthic fluxes from eelgrass beds may be about 10 -fold higher than those from unvegetated areas in Tomales Bay (Sansone et al. 1998). Due to lack of a benthic chamber, the emission of $\mathrm{CH}_{4}$ from sediments was measured by a modified closed chamber incubation method (Barnes \& Owens 1999). This method changes the environment (i.e. pressure and 
temperature) and cannot simulate real in situ conditions such as resuspension, deposit feeding, burrowing, and irrigation, which often significantly change the geochemical characteristics of sediments and overlying water and increase the benthic fluxes (Sansone et al. 1998, Upstill-Goddard et al. 2000). Hence, an underestimation of the $\mathrm{CH}_{4}$ released from the sediments may account for part of the missing source.

Underestimating in situ water column production is also likely to contribute to the missing source. As discussed above, $\mathrm{CH}_{4}$ might be produced in aerobic water columns of the bay with the degradation of methylated compounds such as DMSP produced from the macroalgae, and grazing by bivalves appeared to facilitate the release of DMSP from kelp (Smit et al. 2007). However, the time series incubation method employed in this study only focuses on the microbial activity in the water column itself and neglects the interaction of algae, shellfish, and microbes, which may result in great underestimation of potential contributions from in situ production in the water column. If the in situ production in the water column is indeed the only missing source for $\mathrm{CH}_{4}$ budget in the bay, the net water column production-oxidation rate is estimated to be about $7 \mathrm{nM} \mathrm{d}^{-1}$. This is reasonable based on our incubation results in October 2013, which showed a net water column $\mathrm{CH}_{4}$ increase of $\sim 40 \mathrm{nM} \mathrm{d}^{-1}$ with a DMSP spike. However, our incubation results also showed that $\mathrm{CH}_{4}$ produced might be oxidized rapidly. Hence it is difficult to evaluate how much $\mathrm{CH}_{4}$ is accumulated in the water column over time. Considering the complicated interactions between macroalgae, shellfish, and microbes, mesocosm experiments should be carried out in the future to further understand the in situ water column $\mathrm{CH}_{4}$ production and consumption and to understand the $\mathrm{CH}_{4}$ budget in multi-trophic aquaculture systems like that in SGB.

\section{CONCLUSIONS}

$\mathrm{CH}_{4}$ concentrations in SGB showed obvious seasonal and spatial variation. $\mathrm{CH}_{4}$ concentrations were 3 to 10 times higher in summer and autumn than in spring and winter. Bottom $\mathrm{CH}_{4}$ concentrations were obviously higher than those in the surface water due to sediment release. Higher surface $\mathrm{CH}_{4}$ concentrations occurred in the polyculture areas of kelp and bivalves. Seasonal variation in water temperature, terrestrial freshwater input, and aquaculture activities play significant roles in regulating the spatial and temporal variation of $\mathrm{CH}_{4}$ in the bay. Ground-

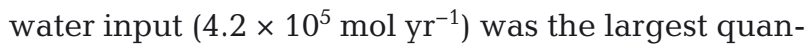
tified source of $\mathrm{CH}_{4}$, followed by sediment release $\left(2.6 \times 10^{5} \mathrm{~mol} \mathrm{yr}^{-1}\right)$, and riverine input $\left(1.4 \times 10^{5} \mathrm{~mol}\right.$ $\left.\mathrm{yr}^{-1}\right)$, while sea-to-air release $\left(2.5 \times 10^{6} \mathrm{~mol} \mathrm{yr}^{-1}\right)$ and export from the bay to the Yellow Sea $\left(8.8 \times 10^{5} \mathrm{~mol}\right.$ $\mathrm{yr}^{-1}$ ) were the dominant $\mathrm{CH}_{4}$ sinks. Net water column production-oxidation was estimated preliminarily to produce $1.7 \times 10^{5} \mathrm{~mol} \mathrm{CH}_{4} \mathrm{yr}^{-1}$; however, this value may have been underestimated due to the neglect of interactions between algae, shellfish, and microbes. There was a great imbalance of sources and sinks, with an apparent missing source of $2.4 \times 10^{6} \mathrm{~mol} \mathrm{yr}^{-1}$, most of which might be attributed to underestimates of in situ water column production and $\mathrm{CH}_{4}$ released from the sediments. Benthic chamber measurements and mesocosm experiments should be carried out in the future to further understand the $\mathrm{CH}_{4}$ budget in multi-trophic aquaculture systems like that in SGB.

Acknowledgements. We thank Professors Jianguang Fang and Zengjie Jiang from the Yellow Sea Fisheries Research Institute, and colleagues from the Laboratory of Marine Biogeochemistry, Ocean University of China, for their assistances in field sample collections. This study was funded by the Ministry of Science and Technology of China through Grant no. 2011CB409802, supported by the National Science Foundation of China through Grant no. 41521064, and by the 111 Project (B13030).

\section{LITERATURE CITED}

Aller RC, Mackin JE, Ullman WJ, Wang $\mathrm{CH}$ and others (1985) Early chemical diagenesis, sediment-water solute exchange, and storage of reactive organic matter near the mouth of the Changjiang, East China Sea. Cont Shelf Res 4:227-251

> Bange HW, Bartell U, Rapsomanikis S, Andreae MO (1994) Methane in the Baltic and North Seas and a reassessment of the marine emissions of methane. Global Biogeochem Cycles 8:465-480, doi:10.1029/94GB02181

> Bange HW, Dahlke S, Ramesh R, Meyer-Reil LA, Rapsomanikis S, Andreae M (1998) Seasonal study of methane and nitrous oxide in the coastal waters of the Southern Baltic Sea. Estuar Coast Shelf Sci 47:807-817

- Barnes J, Owens N (1999) Denitrification and nitrous oxide concentrations in the Humber estuary, UK, and adjacent coastal zones. Mar Pollut Bull 37:247-260

Bates TS, Kelly KC, Johnson JE, Gammon RH (1996) A reevaluation of the open ocean source of methane to the atmosphere. J Geophys Res 101:6953-6961

Bryan J, Rlley J, Williams PL (1976) A Winkler procedure for making precise measurements of oxygen concentration for productivity and related studies. J Exp Mar Biol Ecol 21:191-197

> Canet C, Prol-Ledesma RM, Dando PR, Vázquez-Figueroa V and others (2010) Discovery of massive seafloor gas seepage along the Wagner Fault, northern Gulf of California. Sediment Geol 228:292-303

Chinese Gulf Compilation Committee (1991) Chinese Gulf, 
Vol 3. Ocean Press, Beijing

Cicerone RJ, Oremland RS (1988) Biogeochemical aspects of atmospheric methane. Global Biogeochem Cycles 2: 299-327

> Damm E, Kiene R, Schwarz J, Falck E, Dieckmann G (2008) Methane cycling in Arctic shelf water and its relationship with phytoplankton biomass and DMSP. Mar Chem 109: 45-59

de Angelis MA, Lilley MD (1987) Methane in surface waters of Oregon estuaries and rivers. Limnol Oceanogr 32: $716-722$

EPA (Environmental Protection Agency) (2010) Methane and nitrous oxide emissions from natural sources. http:// nepis.epa.gov/

Fang J, Kuang S, Sun H, Li F, Zhang A, Wang X, Tang T (1996) Mariculture status and optimising measurements for the culture of scallop Chlamys farreri and kelp Laminaria japonica in Sanggou Bay. Mar Fish Res 17:95-102

FAO (Food and Agriculture Organization of the United Nations) (2007) Fisheries and Aquaculture Information and Statistics Service. http://www.fao.org

> Ferrón S, Ortega T, Gómez-Parra A, Forja J (2007) Seasonal study of dissolved $\mathrm{CH}_{4}, \mathrm{CO}_{2}$ and $\mathrm{N}_{2} \mathrm{O}$ in a shallow tidal system of the Bay of Cádiz (SW Spain). J Mar Syst 66: 244-257

Ferrón S, Ortega T, Forja JM (2010) Temporal and spatial variability of methane in the north-eastern shelf of the Gulf of Cádiz (SW Iberian Peninsula). J Sea Res 64: 213-223

Green DS, Boots B, Crowe TP (2012) Effects of nonindigenous oysters on microbial diversity and ecosystem functioning. PLOS ONE 7:e48410

Gu PP, Zhang GL, Li PP, Han Y, Zhao YC (2011) Effect of water-sediment regulation on dissolved methane in the lower Yellow River estuary and it's [sic] adjacent marine area. China Environ Sci 31:1821-1828

Guo X, Ford SE, Zhang F (1999) Molluscan aquaculture in China. J Shellfish Res 18:19-31

Høj L, Olsen RA, Torsvik VL (2008) Effects of temperature on the diversity and community structure of known methanogenic groups and other archaea in high Arctic peat. ISME J 2:37-48

Hornafius JS, Quigley D, Luyendyk BP (1999) The world's most spectacular marine hydrocarbon seeps (Coal Oil Point, Santa Barbara Channel, California): quantification of emissions. J Geophys Res 104:20703-20711

IPCC (Intergovernmental Panel on Climate Change) (2013) Climate change 2013: the physical science basis. Cambridge University Press, New York, NY

> Jiang Z, Li J, Qiao X, Wang G and others (2015) The budget of dissolved inorganic carbon in the shellfish and seaweed integrated mariculture area of Sanggou Bay, Shandong, China. Aquaculture 446:167-174

Karl DM, Tilbrook BD (1994) Production and transport of methane in oceanic particulate organic matter. Nature 368:732-734

Karl DM, Beversdorf L, Björkman KM, Church MJ, Martinez A, Delong EF (2008) Aerobic production of methane in the sea. Nat Geosci 1:473-478

Kelley CA, Martens CS, Chanton JP (1990) Variations in sedimentary carbon remineralization rates in the White Oak River estuary, North Carolina. Limnol Oceanogr 35: 372-383

> Lashof DA, Ahuja DR (1990) Relative contributions of greenhouse gas emissions to global warming. Nature 344:
$529-531$

Li P, Zhang G, Zhao Y, Liu S (2010) Study on distributions and flux of methane dissolved in the Bohai Sea in summer. Adv Mar Sci 28:478-487

Liss PS, Merlivat L (1986) Air-sea gas exchange rates: introduction and synthesis. In: Buat-Ménard P (ed) The role of air-sea exchange in geochemical cycling. NATO ASI Ser 185:113-127

Mao Y, Zhou Y, Yang H, Wang R (2006) Seasonal variation in metabolism of cultured Pacific oyster, Crassostrea gigas, in Sanggou Bay, China. Aquaculture 253:322-333

Mao Y, Yang H, Zhou Y, Ye N, Fang J (2009) Potential of the seaweed Gracilaria lemaneiformis for integrated multitrophic aquaculture with scallop Chlamys farreri in North China. J Appl Phycol 21:649-656

Martens CS, Klump JV (1980) Biogeochemical cycling in an organic-rich coastal marine basin-I. Methane sedimentwater exchange processes. Geochim Cosmochim Acta 44:471-490

> Marty DG (1993) Methanogenic bacteria in seawater. Limnol Oceanogr 38:452-456

> Mau S, Valentine DL, Clark JF, Reed J, Camilli R, Washburn L (2007) Dissolved methane distributions and air sea flux in the plume of a massive seep field, Coal Oil Point, California. Geophys Res Lett 34:L22603

Metje M, Frenzel P (2005) Effect of temperature on anaerobic ethanol oxidation and methanogenesis in acidic peat from a northern wetland. Appl Environ Microbiol 71: 8191-8200

Nightingale PD, Malin G, Law CS, Watson AJ and others (2000) In situ evaluation of air-sea gas exchange parameterizations using novel conservative and volatile tracers. Global Biogeochem Cycles 14:373-387

Nizzoli D, Welsh DT, Fano EA, Viaroli P (2006) Impact of clam and mussel farming on benthic metabolism and nitrogen cycling, with emphasis on nitrate reduction pathways. Mar Ecol Prog Ser 315:151-165

Sansone FJ, Rust TM, Smith SV (1998) Methane distribution and cycling in Tomales Bay, California. Estuaries 21: 66-77

> Shi H, Zheng W, Zhang X, Zhu M, Ding D (2013) Ecological-economic assessment of monoculture and integrated multi-trophic aquaculture in Sanggou Bay of China. Aquaculture 410-411:172-178

Smit AJ, Robertson-Andersson DV, Peall S, Bolton JJ (2007) Dimethylsulfoniopropionate (DMSP) accumulation in abalone Haliotis midae (Mollusca: Prosobranchia) after consumption of various diets, and consequences for aquaculture. Aquaculture 269:377-389

Song G, Liu S, Zhu Z, Zhai W, Zhu C, Zhang J (2016) Sediment oxygen consumption and benthic organic carbon mineralization on the continental shelves of the East China Sea and the Yellow Sea. Deep-Sea Res II 124: 53-63

Striegl RG, Dornblaser M, McDonald C, Rover J, Stets E (2012) Carbon dioxide and methane emissions from the Yukon River system. Global Biogeochem Cycles 26: GB0E05

Sun MS, Zhang GL, Cao XP, Mao XY, Li J, Ye WW (2015) Methane distribution, flux, and budget in the East China Sea and Yellow Sea. Biogeosci Discuss 12:7017-7053

Sun P, Zhang Z, Hao L, Wang B and others (2007) Analysis of nutrient distributions and potential eutrophication in seawater of the Sanggou Bay. Adv Mar Sci 25:436-445

Taniguchi M, Burnett WC, Cable JE, Turner JV (2002) Inves- 
tigation of submarine groundwater discharge. Hydrol Processes 16:2115-2129

Upstill Goddard RC, Barnes J, Frost T, Punshon S, Owens NJ (2000) Methane in the southern North Sea: low salinity inputs, estuarine removal, and atmospheric flux. Global Biogeochem Cycles 14:1205-1217

Wang J, Qu K, Xu Y, Shan B (2008) The distribution and releasing rate of methane in sediment of culture area in Rushan Bay. Mar Fish Res 29:101-107

Wang Q, Guan D, Li M, Li D, Wang J, Yao Z, Zhao H (2011) Distribution and atmospheric fluxes of $\mathrm{CO}_{2}, \mathrm{CH}_{4}$ and $\mathrm{N}_{2} \mathrm{O}$ in surface water of Dalian Bay. Mar Environ Sci 30: 398-403

Wang X, Du J, Ji T, Wen T, Liu S, Zhang J (2014) An estimation of nutrient fluxes via submarine groundwater discharge into the Sanggou Bay-a typical multi-species culture ecosystem in China. Mar Chem 167:113-122

Wanninkhof R (1992) Relationship between wind speed and gas exchange over the ocean. J Geophys Res 97: 7373-7382, doi:10.1029/92JC00188

Wanninkhof R (2014) Relationship between wind speed and gas exchange over the ocean revisited. Limnol Oceanogr Methods 12:351-362

Wiesenburg DA, Guinasso NL Jr (1979) Equilibrium solubilities of methane, carbon monoxide, and hydrogen in water and sea water. J Chem Eng Data 24:356-360

> Xu D, Gao Z, Zhang X, Qi Z, Meng C, Zhuang Z, Ye N (2011) Evaluation of the potential role of the macroalga Laminaria japonica for alleviating coastal eutrophication. Bioresour Technol 102:9912-9918

Yang J, Zhang GL, Zheng LX, Zhang F, Zhao J (2010) Seasonal variation of fluxes and distributions of dissolved methane in the North Yellow Sea. Cont Shelf Res 30: 187-192

Ye W, Zhang G, Zhu Z, Huang D, Han Y, Wang L, Sun M

Editorial responsibility: Marianne Holmer,

Odense, Denmark
(2016) Methane distribution and sea-to-air flux in the East China Sea during the summer of 2013: impact of hypoxia. Deep-Sea Res II 124:74-83

Yvon-Durocher G, Allen AP, Bastviken D, Conrad R and others (2014) Methane fluxes show consistent temperature dependence across microbial to ecosystem scales. Nature 507:488-491

Zeng D, Huang D, Qiao X, He Y, Zhang T (2015) Effect of suspended kelp culture on water exchange as estimated by in situ current measurement in Sanggou Bay, China. J Mar Syst 149:14-24

Zhang G, Zhang J, Kang Y, Liu S (2004) Distributions and fluxes of methane in the East China Sea and the Yellow Sea in spring. J Geophys Res 109:C07011

> Zhang GL, Zhang J, Xu J, Ren JL, Liu SM (2007) Distributions, land-source input and atmospheric fluxes of methane in Jiaozhou Bay. Water Air Soil Pollut Focus 7 : 645-654

Zhang G, Zhang J, Liu S, Ren J, Xu J, Zhang F (2008) Methane in the Changjiang (Yangtze River) estuary and its adjacent marine area: riverine input, sediment release and atmospheric fluxes. Biogeochemistry 91:71-84

- Zhang J, Hansen PK, Fang J, Wang W, Jiang Z (2009) Assessment of the local environmental impact of intensive marine shellfish and seaweed farming - application of the MOM system in the Sungo Bay, China. Aquaculture 287:304-310

> Zhang J, Jiang Z, Wang W (2010) Seasonal distribution and variation of nutrients and nutrients limitation in Sanggou bay. Prog Fish Sci 31:16-25

Zindler C, Bracher A, Marandino CA, Taylor B, Torrecilla E, Kock A, Bange HW (2013) Sulphur compounds, methane, and phytoplankton: interactions along a north-south transit in the western Pacific Ocean. Biogeosciences 10: 3297-3311

Submitted: November 19, 2015; Accepted: June 28, 2016 Proofs received from author(s): August 18, 2016 